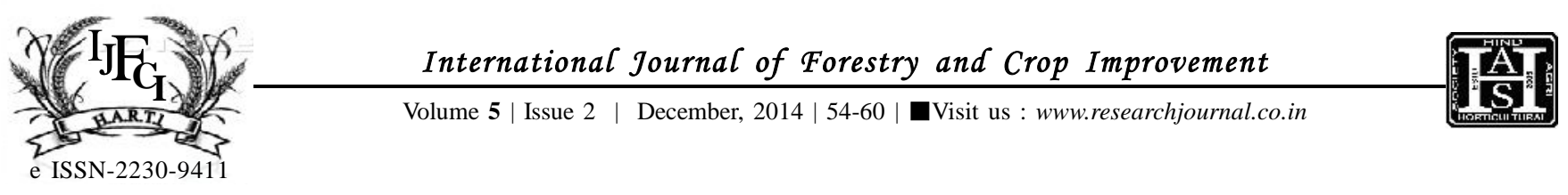

\title{
Quantification of litter fall and assessment of nutrient composition in bamboo (Bambusa vulgaris var. Vulgaris) plantation
}

\author{
C.N. HaRi PRASATh, A. SUdARshan and PraVeEn T. Goroji
}

\begin{abstract}
To quantify the leaf litter bamboo (Bambusa vulgaris var. Vulgaris) plantation/year and assessing nutrient in litter an experiment was conducted in farmer's field at Kottur, Tanjore district during 2014 with three different type of spacing viz., 5 x $5 \mathrm{~m}, 6 \mathrm{x} 4 \mathrm{~m}$ and $7 \mathrm{x} 4 \mathrm{~m}$. The litter fall study was initiated during November 2013 and biometric parameters viz., tree height, DBH and number of culms were recorded. For litter fall quantification, green shade net was tied around the trees at different spacing and litter fall was quantified at 3 months intervals. Litter samples were collected and analysed for nutrient contents. Soil samples were collected, processed and analysed for changes in nutrient status. The result revealed that the growth of bamboo differed from tree spacing and it was observed that $7 \mathrm{x} 4 \mathrm{~m}$ spacing recorded maximum tree height $(8.3 \mathrm{~m})$, number of culms (39.3) and DBH $(4.4 \mathrm{~cm})$. The maximum quantity of litter fall observed in $6 \mathrm{x} 4 \mathrm{~m}$ of about 7000 $\mathrm{kg} \mathrm{ha}^{-1} \mathrm{yr}^{-1}$. The analytical result showed that the nitrogen content in bamboo was varied between 2.042 to 2.099 per cent, total phosphorus between 0.265 to 0.275 and total potassium between 1.061 to 1.072 per cent. With regard to changes in soil properties, soil pH was found to be slightly alkaline (7.48) in nature at the time of establishment of the plantation but over period of five years it decreased to acidic (6.26) and soil EC was decreased from 0.156 to $0.125 \mathrm{dS} \mathrm{m}^{-1}$. There was considerable improvement in available nitrogen, available phosphorus, available potassium and organic carbon status from the initial status $260.3 \mathrm{~kg} \mathrm{ha}^{-1}, 25.63 \mathrm{~kg} \mathrm{ha}^{-1}, 140.63 \mathrm{~kg} \mathrm{ha}^{-1}$ and 0.652 per cent to $314.82 \mathrm{~kg}^{-1}$, $34.27 \mathrm{~kg} \mathrm{ha}^{-1}, 206.50 \mathrm{~kg} \mathrm{ha}^{-1}$ and 0.681 per cent, respectively.
\end{abstract}

KEY WORDS : Litter fall, Quantification, Soil, Nutrient, Spacing, Bamboo

How to cite this Article : Hari Prasath, C.N., Sudarshan, A. and Goroji, Praveen T. (2014). Quantification of litter fall and assessment of nutrient composition in bamboo (Bambusa vulgaris var. Vulgaris) plantation. Internat. J. Forestry \& Crop Improv., 5 (2) : 54-60.

Article Chronical : Received : 24.09.2014; Revised : 27.10.2014; Accepted : 14.11.2014

MEMBERS OF RESEARCH FORUM

Address of the Correspondence :

C.N. HARI PRASATH, Department of Silviculture, Forest College and

Research Institute, METTUPALAYAM (T.N.) INDIA

Email: prasathforestry@gmail.com

Address of the Coopted Authors :

A. SUDARSHAN, Department of Silviculture and Agroforestry, College of Forestry, Kerala Agricultural University, THRISSUR (KERALA) INDIA

- - - - - - - - -

PRAVEEN T. GOROJI, Krishi Vigyan Kendra, Sirsi, UTTARA KANNADA (KARNATAKA) INDIA 